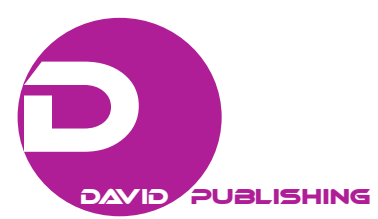

\title{
Bank Criminal Act: Case of Fraud Using Letter of Credit-Bank as a Victim*
}

\author{
Pwee Leng \\ Petra Christian University, Surabaya, Indonesia \\ Handjaya A. Hugan \\ Narotama University, Surabaya, Indonesia
}

\begin{abstract}
Letter of Credit (L/C) is a payment method offered by bank for settling the foreign trade. The existence of L/C is a means capable of providing guarantee for the interests of the sellers and buyers. In the event of default by either party, either the seller or the buyer, the bank as the L/C issuer will provide payment guarantee for the seller or the waiver of payment for the buyer. The bank's risk in issuing the $\mathrm{L} / \mathrm{C}$ is regarding with the weakness of $\mathrm{L} / \mathrm{C}$. In Article 5 of UCP 600, it is emphasized that in transactions using L/C, banks deal only with documents, not dealing with goods, or other implementation. In Article 14a of UCP 600 it is affirmed that the L/C payments are based on the suitability between the L/C requirements and the submitted documents viewed under "on their face”. The bank authority as the guarantor which only deals with the documents in making payments causing the $\mathrm{L} / \mathrm{C}$ instrument is often used in fraud against the bank. Many banking fraud cases that occur in Indonesia take advantage of L/C weakness. This paper will discuss the occurrence of criminal acts in the banking by exploiting weaknesses in the $\mathrm{L} / \mathrm{C}$ that makes the bank as a victim. In addition, this paper aims to explain the effort to overcome the criminal acts that occurred at the issuing bank as a victim by using $\mathrm{L} / \mathrm{C}$. The discussion in this paper emphasized the application of laws and regulations applicable to indict the perpetrators of criminal acts in the banking sector by exploiting weaknesses of L/C. Aspects of the discussion of a criminal offense are based on the Act No. 10 of 1998 concerning banking, and under the provisions of the Criminal Code.
\end{abstract}

Keywords: Letter of Credit, bank criminal act, fraud against bank

\section{Introduction}

Foreign trade transactions or popularly known as export import transactions are trade transactions conducted by sellers in a country with buyers in other countries. In other words, export-import transaction is a long-distance trade transaction. Thus, the main and most important element in export-import transactions is trust among the parties. Therefore, in order to protect the possibility of one of the transacting parties not fulfil the liability, the guarantee for an agreed transaction is required. This kind of the guarantee is Letter of Credit

\footnotetext{
* This paper is a summary of the thesis of legal scholars on behalf of Pwee Leng, which developed the discussion into the criminal shutter by Handjaya A. Hugan.

Pwee Leng, S.E., S.H., M.Kom., lecturer, Finance Program Faculty of Economic, Petra Christian University, Surabaya, Indonesia

Handjaya A. Hugan, S.H., master of law student (notary), Law Faculty, Narotama University, Surabaya, Indonesia.

Correspondence concerning this article should be addressed to Pwee Leng, Department of Management, Faculty of Economy, Petra Christian University, Siwalankerto 121-131, Surabaya 60236, Indonesia.
} 
$(\mathrm{L} / \mathrm{C})$.

$\mathrm{L} / \mathrm{C}$ is one of the payment media and also the financing medium offered by the bank for foreign trade such as import and export transactions. According to Bank Indonesia, "Letter of Credit is a promise from the issuing bank to pay a sum of money to the exporter as long as it is able to meet the terms and conditions of the Letter of Credit”. In Uniform Customs and Practice for Documentary Credits, ICC Publication No. 600 of 2007 (UCP 600), the definition of Letter of Credit is

Each agreement, in various names or with various purposes, issued by a bank (Issuing Bank) acts upon the request and instruction of a customer (Applicant) or on his own behalf, to make payment to a third party or its proxy (the person designated by the beneficiary/L/C recipient) or authorize another bank to make payment, or to accept and pay bills of exchange/draft, or authorize other banks to negotiate upon the submission of the designated documents, provided that the documents meet the terms and conditions of $\mathrm{L} / \mathrm{C}$.

In its use, $\mathrm{L} / \mathrm{C}$ as a method of payment is a safe financing facility for importers and exporters, especially for exporters who have the merchandising. For the exporter or seller, the most important element in a transaction is the assurance of payment as agreed with the buyer. For the buyer or importer, receiving goods on time is the most important element because the goods coming late will not be worth selling again (if fashionable goods that will quickly be abandoned by consumers) or no longer useful for production (if raw materials).

Therefore, the existence of $\mathrm{L} / \mathrm{C}$ is a means capable of providing guarantee for the interests of the sellers and buyers. In the event of default by either party, either the seller or the buyer, the bank as the L/C issuer will provide payment guarantee for the seller or the waiver of payment for the buyer. Almost all foreign trade transactions generally use $\mathrm{L} / \mathrm{C}$ because of the guarantee power provided in the use of $\mathrm{L} / \mathrm{C}$, mainly on the first transactions done between the seller and the buyer.

The fact that there is a seller's rights regarding the payment of the transaction and the buyer's right regarding the receipt of goods guaranteed through the use of $\mathrm{L} / \mathrm{C}$ does not eliminate the possibility of occurrences of deviations that will be a constraint in the settlement of transactions using L/C. Generally, in the process of negotiation made by the seller in order to request payment for the transaction which has been done or will be done, it requires the inspection of document's requested or required to be prepared by the seller as stated in the L/C by the bank and forwarded to the buyer. In case of any discrepancy, the seller is obliged to repair or provide all documents required in L/C. Payments will not be made by the bank as long as all the required documents have not been met by the seller, even if the transaction includes a Sight Letter of Credit unless the deviation is ignored at the buyer's request. If the buyer accepts that the deviation is negligible, the issuing bank of $\mathrm{L} / \mathrm{C}$ shall make payment to the negotiating bank which will be forwarded to the seller. This is where the weakness of L/C use occurs. That is, the bank as a guarantor only relates to documents, even the bank can keep running a negotiated process of L/C payment to the seller despite the occurrence of irregularities as long as the buyer gives the "ignored" instructions on the deviation that occurred.

The conditions occurring in payments using $\mathrm{L} / \mathrm{C}$ as described above are set out in the universal provision for payment methods using Letter of Credit. The Uniform Customs and Practice (UCP) for Documentary Credit is one of the products of International Chamber of Commerce (ICC) established in 1919. The agency is based in Paris with a view to serving the business world by promoting trade, investment, opening up markets for goods and services, and promoting capital flows. The products of the ICC were published in 1933 and revised in 2007. The result of the 2007 revision is called UCP 600 valid on July 1, 2007. The mention of UCP 600 is 
based on the number of UCP revised 2007 publication number 600. Before the provision of UCP 600, the UCP 500 provisions shall apply. The provisions of UCP 500 are valid from January 1, 1994 to July 1, 2007.

Formally UCP 600 does not revoke UCP 500. This means that in UCP 600 there is no provision for revocation of UCP 500. UCP 600 publisher-ICC states that UCP 600 is valid from 1 July 2007, but does not revoke or declare UCP 500 not valid anymore since then. Therefore, based on the principle of freedom of contract, the parties in the L/C can still enter into an agreement to enact UCP 500 or UCP 600. Subsequently in Article 5 of UCP 600, it is emphasized that in transactions using L/C banks deal only with documents, not dealing with goods, or other implementation. The provisions in the UCP are the basis for the principle of attachment to documents in L/C. In Article 14a of UCP 600 it is affirmed that the L/C payments are based on the suitability between the $\mathrm{L} / \mathrm{C}$ requirements and the submitted documents viewed under "on their face". The material of this provision is the basis for "determination of conformity".

Because bank as the guarantor only pays attention to or checks the required documents, it is possible that the parties who transact will use it to commit fraud against the bank. The example of bank fraud that often occurs due to weakness of $\mathrm{L} / \mathrm{C}$ is fictitious $\mathrm{L} / \mathrm{C}$. The fictitious $\mathrm{L} / \mathrm{C}$ could happen if any collusion among the seller and the buyer. In this fictitious case actually there is no transaction, but the seller and buyer making fake transaction that means all of the documents presented are fake also. Generally, the fictitious L/C case always involves parties outside the bank such as exporters and importers as well as parties from within the bank itself.

One of the fundamental things is that UCP does not regulate fraud issues in $\mathrm{L} / \mathrm{C}$ transactions. Fraud in $\mathrm{L} / \mathrm{C}$ transaction is not regulated in UCP 500 (Article 15) or in UCP 600 (Article 34). Fraud is a legal arrangement in the Criminal Law. The case of fraud or collusion that makes the bank as a victim can be categorized as a crime in the field of banking.

\section{Criminal Offenses Concerning Banking}

There are two terms that are often used interchangeably in terms of criminal offenses concerning banking, although the intent and scope may be different. First, "Banking Crime” and secondly, "Crime in Banking”. There are differences in the use of terminology in banking criminal act, such as a crime in the field of banking, crime against banking, and banking crime. This term difference evolves to the notion of banking crime. Banking crime can be interpreted as a crime "in the banking sector" which in this sense includes all unlawful acts that are related to the banking business. This sense also covered banks as perpetrators and banks as victims.

Act no. 10 of 1998 concerning Banking Law does not formulate understanding about banking crime. This Act only categorizes several acts that belong to crime and can be categorized as a violation. There is also a distinguishing understanding of banking crime. Criminal acts in the banking sector are all types of unlawful acts related to activities in running a bank business, whether the bank as a target or as a means, while banking crime (crime banking) is a crime committed by the bank.

Banking crime is any crime involving banking, for example a person robbing a bank is a crime in the banking sector, as well as illegal transfer of accounts which is a crime in the banking sector, so the understanding is very broad. On the other hand banking crime is a form of action that has been created by the banking law which is a prohibition and necessity, for example the ban on setting up a black bank and leaked bank secrets. This term difference affects law enforcement. Banking crime will be handled through criminal provisions regulated in banking law, while crime in the banking sector is handled through laws outside the banking law. 
The criminal act of banking contains an understanding of the criminal act solely done by bank or bank person, while the crime in the banking sector is more neutral and wider because it can include criminal acts committed by people outside and inside the bank. The term "criminal offense in banking" is intended to accommodate all types of unlawful acts related to activities in the conduct of a bank's business. Criminal acts in banking according to Act Number 7 of 1992 concerning Principles of Banking, as amended by Act Number 10 of 1998 concerning Amendment to Act Number 7 of 1992 concerning Banking (Banking Law) are a criminal offense making the bank as a means to commit the crime itself (crime against the bank).

To determine a person or corporation to be a victim or not, it is necessary to know in advance what the acts are called crimes or criminal acts. Some criminal offenses that can be categorized as banking crimes and have been regulated in legislation are:

(1) In the Criminal Code II Chapter X on Counterfeit Currency and Banknotes, namely Articles 244, 245, 246, 249, and 250;

(2) In Act no. 10 of 1998 concerning Banking Law;

- Criminal acts related to licensing (Article 46)

- The criminal act pertains to bank secrecy (Articles 47 and 47a)

- The criminal offense relates to bank supervision (Article 48)

- The criminal act relates to the business activities of the bank (Article 49)

- Criminal acts relating to affiliated parties (Article 50)

- Criminal acts relating to shareholders (Article 50a)

(3) Criminal Act as regulated in the Law concerning Central Bank.

Characteristic in banking crime is that bank can as victim or as perpetrator, banks as victims such as fraud, forgery of bank letters, and banks as perpetrators, such as window dressing, overstating interest rates, improper credit cards, running a bank in a bank, running a bank without a license, and running a business which resembles a bank. The modus operandi in the case of banks as victims is not so much, usually only in the form of document forgery, embezzlement, and corruption, the perpetrators are usually people, not corporations. If the perpetrator is a bank (as a corporation), the modus operandi can vary. This crime is categorized as criminal banking and is always done in an organized manner. In this case banking activities are only a camouflage because all its activities are indeed systemic violation of the law for the purpose of making a profit. The criminal banking anatomy is usually the most popular which is money laundering and window dressing.

\section{Special Regulation Related to Criminal Offenses in Banking}

In addition to those stipulated in the Law on Banking, criminal acts in the banking sector are also related to other fields so there is a need for a special arrangement to follow the journey of crime in the banking sector, to then overcome it. The special arrangements are arrangements in special laws and regulations, namely the Criminal Code.

As a strict regulation of all criminal offenses in general, the Criminal Code can serve as a reference for tackling criminal offenses in the banking sector. This can happen because of more and more perpetrators and motives in criminal acts in the field of banking, where the perpetrator is committing a general crime as regulated in the Criminal Code. The increasing variety of banking activities and business can also be one of the more open factors for the opportunity to commit a crime. 
In the case of a bank as a victim, the articles of the Criminal Code are used to deal with criminal offenses in the banking sector, including articles 263, 264, and 378. Article 263 of the Criminal Code provides for a criminal penalty for any person who makes a false letter or falsifies a letter which may incur a right, an engagement or a debt relief, or that is designated as evidence of a legal case in order to use or order another person to use the letter as if the contents are true and not falsified, if such use can cause harm. Based on the Article 263, the actions taken by bank employees or affiliated parties that issue fake letters or documents relating to the bank in the submission of incorrect bank product information hence against it may be subject to Article 263 of the Criminal Code because it is included in the act of fraud. Article 264 of the Criminal Code provides for imprisonment for falsification of letters primarily of authentic deeds, Sovereign Debt Instruments or parts thereof or of a public institution, or debt of an association, foundation, corporation, dividend or interest from one of the debt securities, or evidence issued in lieu of those letters, as well as letters of credit or commercial papers intended to be circulated. The elements of fraud crimes set forth in Article 378 of the Criminal Code include objects of fraud with the intent of benefiting oneself or others by unlawfully and using false names, false positions, and deceit.

Based on the above description, the elements contained in the Article are also elements committed in the practice of banking crime which can be seen clearly in the case of Bank Pembangunan Indonesia (BAPINDO) with Golden Key Group (GKG) in 1994.

\section{Facts of the BAPINDO-Golden Key Group Case}

This case is a case of giving credit facility amounting to Rp900,000,000,000.00 from BAPINDO to PT. Graha Swakarsa Prima (GSP) a subsidiary of Golden Key Group (GKG) with Eddy Tansil as President Director and the largest shareholder (60\%). In 1989 with its letter No: 07/GSP/89 dated June 16, 1989 GSP applied for investment credit to purchase the plastic machinery equipment factory amounting to Rp225,900,000,000.00 and for working capital credit of Rp24,730,000,000.00 to establish Styrene Monomer, High Impact Polystyrene, Acrylonitrile Butadibe Styrene, and Styrene Acrylonitrile factories. That investment credit is used to purchase machinery/equipment with Lucky Engineering Co. Ltd. supplier/exporter in Korea who pays by opening Usance L/C 180 days with shipment on 18 months later. At the time of application for this credit which is filed, there has been no trade agreement between GSP and the beneficiary (Lucky Engineering), so the amount submitted for credit application is only estimation from Eddy Tansil.

The proposed credit application was accompanied by a proposal from the project for which the credit was applied and it was later revealed that most of the data submitted in the proposal were incorrect. The application of GSP is then approved by BAPINDO which is an investment credit of US\$125,500,000 (equivalent to Rp360,000,000,000) for L/C opening consisting of domestic L/C (SKBDN) of US\$50,800,000 and L/C for machine import from Korea of US\$74,700,000. Before L/C is opened the GSP must submit a trading contract with Lucky Engineering Korea as the beneficiary and deliver a deposit of Rp3,600,000,000 (approximately 1\% of the value of $\mathrm{L} / \mathrm{C}$ ) as cash collateral. The two main requirements are not submitted by GSP, until L/C is opened by BAPINDO. Usance L/C was sent by BAPINDO through telex to Korea Exchange Bank as Advising Bank. L/C was opened for the first phase of US\$40,000,000 with No: 98/94/1391/PMDN-A/B 89 dated December 27, 1989.

In the next process there is a changing of the $\mathrm{L} / \mathrm{C}$ type from Usance $\mathrm{L} / \mathrm{C}$ to Red Clause $\mathrm{L} / \mathrm{C}$ including the beneficiary not accompanied by a deep analysis from BAPINDO. The changing was made by Maman 
Suparman as the head of the BAPINDO branch, only with the oral approval from the Board of Directors of BAPINDO. Under the impact, $\mathrm{L} / \mathrm{C}$ can be disbursed before goods are delivered or without delivery of documents by receiver. Furthermore, $\mathrm{L} / \mathrm{C}$ is opened gradually as well as loan disbursement for the construction of the factory. In its development there has been a change in disbursement mechanism including the beneficiary change which is not accompanied by a deep analysis from BAPINDO. At that time the BAPINDO explained that the credit for the construction of the plant is to finance the process of development of the current plastic seeds. Credit for the purchase of the machine is used for the opening of Usance $\mathrm{L} / \mathrm{C}$ which is then changed to Red Clause L/C, but the machine has not arrived because the plant has not been completed.

Loans already disbursed are for the construction of the plant by $50 \%$, while for the purchase of the machine has been withdrawn entirely because the Usance $\mathrm{L} / \mathrm{C}$ is changed to Red Clause $\mathrm{L} / \mathrm{C}$. Red Clause $\mathrm{L} / \mathrm{C}$ is the $\mathrm{L} / \mathrm{C}$ that is liquefied before the goods are shipped to the buyer. Internationally this type of $\mathrm{L} / \mathrm{C}$ is rarely published because of the enormous risks in the buyer's factory especially for the bank making the payment.

The provision of credit facilities to GSP not through appropriate applying procedures in BAPINDO, even the analysis is done simply based only on a recommendation from the high officials of the state. The official made a recommendation because of the involvement of the President's son as a shareholder of GSP and resigned as a shareholder after the credit was approved.

The changing of Usance L/C being Red Clause L/C is done very recklessly and not carefully, because the risk of red clause $\mathrm{L} / \mathrm{C}$ is on the buyer side. Red Clause L/C gives the seller opportunity to ask advance payment in several period terms without presenting the shipping documents first. This means that payments will be sent to the seller even if the seller is defaulted. This carelessness will obviously pose a risk to BAPINDO because the funds used to pay the Red Clause L/C are from BAPINDO's credit facility to GSP and not from GSP's personal funds. So if there is a conspiracy between the seller (beneficiary) and the GSP to commit fraud to the bank, then the loss is on BAPINDO because the fund will be changed to be the $\mathrm{L} / \mathrm{C}$ receivables that burden the financial of BAPINDO.

The basis for the crediting error is the credit given prior to a written credit agreement, so the Golden Key Group obtains the credit without going through the prevailing banking provisions, namely the credit agreement that must be written. A credit agreement even if there is consensus or an agreement is also required to be specifically written. This is based on banking provisions which are lex specialis.

In the case of BAPINDO-GKG, it was revealed that the buyer, Eddy Tansil through his company GKG managed to commit fraud or embezzlement of credit from BAPINDO. Transactions conducted by GKG with the seller are a transaction using fictitious L/C which is an engineering from Eddy Tansil himself. As a result, the state loses up to trillions of rupiah.

\section{Literature Review of Banking Crime}

Based on Article 6 of Act no. 7 of 1992 as amended by Act no. 10 of 1998 on Banking, the normal activities of commercial banks include collecting funds from the public in the form of savings, giving credit, issuing letters of credit; buying, selling, or guaranting at their own risk or at the request of the customer against notes papers, letters of credit, government guarantees, certificates of Bank Indonesia, short-term trade papers, moving money, placing funds, borrowing funds, or lending funds to other banks, receiving payments on securities bills, providing a place to store goods and securities, conducting custodial activities for the benefit of 
others based on the contract, placing funds from customers to other customers in the form of securities, buying through auction of collateral, doing factoring activities, crediting card business, providing financing and/or performing other activities based on sharia principles, undertaking other activities which are commonly practiced by banks as long as do not conflict with this law or the prevailing laws and regulations.

All forms of activities above are banking activities in normal or should be done by the bank, but there are banking activities that have certain motives that exceed or not in accordance with applicable regulations. This kind of activity is called banking crime.

Currently, there is still no agreement on the use of criminal terms that are detrimental to the financial economy associated with banking institutions. Some use the term crime banking, some use the term criminal act in the field of banking, and some even use both, based on the rules that are violated. In this case Moh Anwar distinguishes these two notions based on differences in the regulatory treatment of unlawful acts in connection with activities in the conduct of bank business.

The criminal act of banking contains an understanding of the criminal act solely done by bank or internal bank person, while the crime in the banking sector is more neutral and wider because it can include criminal acts committed by people outside and inside the bank. The term "criminal offense in banking" is intended to accommodate all types of unlawful acts related to activities in the conduct of a bank's business.

The dimensions of banking crime can be a crime against a bank, a bank crime against another bank, or a bank crime against an individual so that the bank can become a victim or a perpetrator. Banking crime is not limited to a certain space, which can pass through the territorial boundaries of a country, can happen instantaneously, but also can take some time. Banking crime can occur in all aspects of the banking world or closely related to banking activities and more broadly including other financial institutions. While the provisions that could be violated in banking crimes both written and unwritten also include customary norms in the banking sector, but they are all governed by criminal sanctions. The scope of the perpetrators of banking crimes can be done by individuals and legal entities (companies). The popular definition states that a criminal offense in the banking sector is a criminal act that makes the bank as a means and target of the crime.

\section{Crimes Related to the Bank’s Business}

Article 49 Paragraph (1) of the Banking Law states that a member of the Board of Commissioners, Board of Directors or a bank employee who deliberately:

(1) Making or causing false records in the books or in reports, as well as in documents or reports of business activities, reports of transactions or accounts of a bank;

(2) Eliminating or excluding or causing non-recording of books or reports, nor in documents or reports of business activities, transaction reports or bank accounts;

(3) Changing, obscuring, hiding, deleting, or omitting any record keeping in the books or in reports, nor in documents or reports of business activities, transactions or accounts of a bank, or intentionally altering, obscuring, removing, concealing, or destroying the accounting records.

Threatened with imprisonment of at least 5 (five) years and a maximum of 15 (fifteen) years and a fine of at least Rp10,000,000,000 (10 billion rupiah) and a maximum of Rp200,000,000,000 (two hundred billion rupiah).

Article 49 of the Paragraph (2) of Banking Law states that a member of the Board of Commissioners, Board of Directors or a bank employee who intentionally: 
(1) Requesting or accepting, allowing, or accepting to receive any remuneration, commission, additional money, service, money, or valuables, for his personal gain or for the benefit of his family, in order to obtain or seek for others for an advance, bank guarantee, or credit facilities of a bank, or in the course of purchase or discount by the bank on notes, promissory notes, checks, and trade papers or other evidence of liability, or in order to give consent to others to withdraw funds exceeding the credit limit at the bank;

(2) Not implementing the necessary measures to ensure compliance with the provisions of this law and the provisions of other laws and regulations applicable to banks.

Threatened with imprisonment of at least 3 (three) years and a maximum of 8 (eight) years and a fine of at least Rp5,000,000,000 (five billion rupiah) and at most Rp100,000,000,000 (100 billion rupiah).

Furthermore, Article 50 of the Banking Law states that affiliated parties who intentionally do not carry out the necessary measures to ensure a compliance with the provisions of this Law and other laws applicable to banks are threatened with imprisonment of at least 3 (three) years and a maximum of 8 (eight) years and a fine of at least Rp5,000,000,000 (five billion rupiah) and at most Rp100,000,000,000 (100 billion rupiah).

Article 50a of the Banking Law stipulates that shareholders who deliberately have the Board of Commissioners, Board of Directors, or employees of a bank to commit or not take action that result in the bank not implementing the necessary measures to ensure the bank's compliance with the provisions of this law and the statutory provisions - any other law applicable to the bank, is punishable by imprisonment of at least 7 (seven) years and a maximum of 15 (fifteen) years and a fine of at least Rp10,000,000,000 (10 billion rupiah) and a maximum of Rp200,000,000,000 (200 billion rupiahs).

The classification of criminal offenses in the banking sector can also be classified into criminal offenses in the form of crime and offenses in the form of a violation. The distinction between crime and offense is generally distinguished by quantitative distinctions (concerning the weight or lightness of criminal threats). The acts categorized into criminal offenses indicate that such acts shall be subject to a more severe penalty of punishment than if merely as an offense.

The classification of these crimes has also been regulated in Act Number 7 of 1992 concerning the Principles of Banking, as amended by Act Number 10 of 1998 concerning Amendment to Act Number 7 of 1992 concerning Banking, namely in Article 51 which states that a criminal offense under articles 46 through 50 (excluding Article 48, paragraph 2) is a crime, while Article 48 paragraph (2) is a violation.

In addition to criminal sanctions, parties who commit criminal offenses in the banking sector will also be subject to additional sanctions, namely administrative sanctions. This is in accordance with the provisions contained in Article 52 of Act Number 7 of 1992 concerning the Principles of Banking. The administrative sanctions include: money fines, written reprimands, decrease in level of bank soundness, prohibition to participate in clearing activities, freezing of certain business activities, whether for branch offices certain as well as for the bank as a whole, dismissal of bank management; and inclusion of members, administrators, bank employees, shares holder in the list of disgraceful people in banking.

The criminal act as regulated in Act No. 10 of 1998 is a special criminal act. According to the Decree of the Minister of Justice of the Republic of Indonesia Number: M01.PW.07.03 Year 1982 dated February 4, 1982 on Guidelines for Implementation of the Criminal Procedure Code (KUHAP) mentioned banking crime is included in special crime (as the explanation of Article 284 KUHAP). Although Law number 10 of 1998 does not regulate special procedural law regarding banking crime, because it is regulated outside the Criminal Code, it is a special banking crime. 


\section{Arrangement of Criminal Acts in the Field of Banking in the Criminal Code}

Criminal offenses in the banking sector may also apply articles to the Criminal Code if the bank becomes a victim of a criminal act of fraud (Article 263 of the Criminal Code), criminal act of embezzlement (Article 372 of the Criminal Code), criminal act of embezzlement in office (Article 362 of the Criminal Code). The burglary case of BNI 46 New York by one of its former employees is subject to Article 362 of the Criminal Code concerning theft, which is one example of the bank as a victim of a banking criminal act, so the articles of the Criminal Code applied.

In addition, corruption in the field of banking can apply Law number 20 of 2001 on Amendment to Law number 31 of 1999 on the Eradication of Corruption in conjunction with Law number 30 year 2002 on Corruption Eradication Commission. The provisions of the law on corruption are usually applied to cases that affect government banks. The criminal act of corruption is a part of the special criminal law when viewed from the material regulated because it is directly or indirectly intended to minimize the occurrence of leaks and irregularities to the state's financial and economic. In this case the Law is used to facilitate ensnarement of the perpetrator, impose severe punishment, and obtain substitute money for state losses.

The Articles of the Indonesian Criminal Code used to deal with criminal offenses in the banking sector are, among others: Article 263, Article 264, Article 362, Article 363, Article 372, and Article 378. Based on the elements of Article 263, the actions of bank employees or affiliated parties issuing fake letters or documents relating to the bank in the submission of incorrect bank product information shall be subject to Article 263 of the Indonesian Criminal Code as it is included in the act fraud. Article 264 paragraph (1) of the Criminal Code states that falsification of letters if done by letter of credit or securities intended to be circulated may be imprisoned by a maximum of eight years. Article 362 applies to unlawful acts with a bank as the target or an object of a criminal offense. Theft in banks is often done outsiders together with bank employees, or bank managers and directors. This criminal act also makes the bank as a target and object of criminal act. Therefore it can be charged with Article 363 that is theft committed by two or more persons. Article 372 of the Criminal Code formulates the threat of punishment for actions not originating from crime, is categorized as embezzlement, but the final outcome of the offense has violated the rights of others legally valid. Article 378 of the Criminal Code expressly implies the threat of punishment for acts containing elements of fraud, namely, first, to persuade people to approve a debt (the object of fraud); second, in order to benefit themselves or others by against the law; and third, using false names, false positions, tricks, and lying.

\section{Letter of Credit in Banking Practice}

In general, Letter of Credit $(\mathrm{L} / \mathrm{C})$ is used to finance the contract of sale of goods or long-distance sales crossing the boundaries of a state territorial between buyers and sellers who do not know each other well. However, $\mathrm{L} / \mathrm{C}$ is not a guarantee or a negotiable instrument. How to pay by using $\mathrm{L} / \mathrm{C}$ is not separated from the terms and conditions set by the parties concerned. One of the requirements is that a payment can be made if it has been submitted documents to the bank that formally meet the requirements stipulated in the L/C. Payment by $\mathrm{L} / \mathrm{C}$ in its implementation involves banking services that are located in different countries. Therefore, the use of payment method with L/C requires the suitability of payment method between the banks, which is realized by the existence of regulatory uniformity. L/C literally can be translated as a debt or letter of receivables or billing, but in fact $\mathrm{L} / \mathrm{C}$ is a promise of payment if and after fulfilling certain conditions. 
In Uniform Customs and Practice for Documentary Credits , ICC Publication No. 600 of 2007 (UCP 600), the definition of Letter of Credit is

Each agreement, in various names or with various purposes, issued by a bank (Issuing Bank) acts upon the request and instruction of a customer (Applicant) or on his own behalf, to make payment to a third party or its proxy (the person designated by the beneficiary/L/C recipient) or authorize another bank to make payment, or to accept and pay bills of exchange/draft, or authorize other banks to negotiate upon the submission of the designated documents, provided that the documents meet the terms and conditions of L/C.

The L/C definition under UCP is the promise of the issuing bank to make a payment or authorize another bank to make payments to the recipient for the submission of documents in accordance with $\mathrm{L} / \mathrm{C}$ requirements. The essence of the L/C definition according to UCP is that the L/C is the promise of payment. The issuing bank shall make payment to the recipient either directly or through another bank upon the instruction of the applicant promising to pay back to the issuing bank.

The definition of L/C according to Bank Indonesia is a promise from the issuing bank to pay a sum of money to the exporter as long as the exporter can meet the terms and conditions of the Letter of Credit. The opinion of Bank Indonesia is the core of the $\mathrm{L} / \mathrm{C}$ which is the promise of payment. The payment of $\mathrm{L} / \mathrm{C}$ to the recipient may be made directly by the issuing bank or through another bank as its proxy.

In practice, commercial banks in Indonesia follow the L/C definition according to UCP. This is because at the time of enactment of Government Regulation no. 16 of 1970 (amended by Government Regulation No. 11 of 1976) and both have been revoked by Government Regulation no. 1 of 1982, Bank Indonesia issues the Association of Foreign Exchange Flows Regulations (HKPLLD) as the implementation provisions requiring that $\mathrm{L} / \mathrm{Cs}$ received from overseas as well as those issued from Indonesia to abroad are subject to UCP applicable which is UCP 290 (valid from 1 October 1975). As a condition of its implementation, Bank Indonesia issues Circular Letter of Bank Indonesia no. 17/14/ULN dated September 29, 1984 which requires that the L/C issued by the foreign exchange bank in Indonesia is subject to the prevailing UCP, UCP 400, which entered into force on 1 October 1984. Then the Bank Indonesia Circular Letter no. 17/14/ULN is revoked by Bank Indonesia Circular Letter no. 26/34 /ULN dated December 17, 1993 which regulates L/C subjection on UCP applicable UCP 500. Bank Indonesia Circular Letter no. 26/34 /ULN gives the foreign exchange bank the option to determine the $\mathrm{L} / \mathrm{C}$ it submits under or not to UCP 500. In practice, the foreign exchange bank is still subject to the L/C definition following UCP 500 even though UCP 600 has been published.

Letter of Credit as a means of payment is in great demand internationally because of the elements of the promise of payment available in this instrument. L/C recipients who sell goods to L/C applicants feel secure because of the promise of payment from the issuing bank. Conversely, the applicant also feels secure buying goods by way of payment using $\mathrm{L} / \mathrm{C}$ because it will receive the documents it wants because the fulfillment is a condition of L/C payments.

In general, the issuing bank does not directly make payments to the recipient, but through another bank authorized by $\mathrm{L} / \mathrm{C}$ to do so. Another bank acts according to the authorization it receives from the issuing bank. If the other bank concerned acts outside its authority of attorney then the bank is solely responsible for any risks that may arise. If the other bank acts according to the authorization receiving from the issuing bank, then the other bank is entitled to a reimbursement from the issuing bank for the payment it has made to the addressee. Furthermore, the issuing bank shall also be entitled to receive reimbursement from the applicant for any 
payment made to another bank. This repayment is called reimbursement.

\section{Bank Documents, Payments, and Guarantee in Letter of Credit}

The main thing to note in the use of $\mathrm{L} / \mathrm{C}$ as a means of financing and payment of export import transactions is on the documents required in the L/C. The basis for bank transactions is focused on documents only, so the beneficiary must meet the specific requirements related to the documents as stated in the $\mathrm{L} / \mathrm{C}$ accompanied by the draft itself to obtain payment. The document is evidence of the implementation by the beneficiary regarding the sales contract on its part and the transfer of ownership of the goods. In this way the buyer obtains a certainty of receiving the goods which have been approved and fixed payment by the buyer. Similarly, the bank concerned with this transaction is granted the right of ownership of the goods, thereby ensuring that the buyer will fulfill its obligations under the agreement of the $\mathrm{L} / \mathrm{C}$.

According to the UCP, the L/C payment requirement is the submission of documents in accordance with $\mathrm{L} / \mathrm{C}$ requirements. The submission of these documents is a condition for $\mathrm{L} / \mathrm{Cs}$ to be paid or accepted and paid at maturity. Those documents are the main basis for determining the bank's attitude in the payment of $\mathrm{L} / \mathrm{C}$.

Article 4 of UCP 500 contains the following provisions: "In credit operations all parties concerned deal with documents, and not with goods, services, and/or other performances to which the documents may relate”. Furthermore, Article 5 of UCP 600 contains the following provisions: "Banks deal with documents and not with goods, services, or performance to which the document may relate”. In this case the emphasis of the difference between UCP 500 and UCP 600 lies on the party implementing the L/C. UCP 500 says the party implementing the $\mathrm{L} / \mathrm{C}$ is all parties, including the issuing bank, the designated bank, and the recipient. Meanwhile, UCP 600 says the party carrying out the L/C is a bank, meaning only the issuing bank and the appointed bank.

Subject to the provisions of Article 4 of UCP 500 or Article 5 of UCP 600, the bank shall pay the documents filed as long as the submitted documents meet the $\mathrm{L} / \mathrm{C}$ requirements. Banks in implementing $\mathrm{L} / \mathrm{C}$ deal with documents only. So the core of $\mathrm{L} / \mathrm{C}$ realization is the suitability of documents with $\mathrm{L} / \mathrm{C}$ requirements. Therefore, banks are required to conduct research on documents to determine whether the documents can be paid or not. The benchmark specifying document is UCP. The Bank shall conduct research on the documents submitted to determine whether the documents are in compliance with the $\mathrm{L} / \mathrm{C}$ requirements. According to Article 13a of UCP 500, the measurement of conformity is based on international banking practice standards. Inconsistent documents one to another are a reflection of the lack of compliance between documents and $\mathrm{L} / \mathrm{C}$ requirements. Meanwhile, according to Articles 14a and d of UCP 600, the suitability measurement is based on the presence or absence of conflict between the document and the data in the document, other required documents or $\mathrm{L} / \mathrm{C}$. Basic measurement is to determine whether or not a conflict based on $\mathrm{L} / \mathrm{C}$, the document itself and international banking practice standards .

The decision to determine documents physically (formally) has or has not been in accordance with the L/C requirement and substantially the documents have been or have not been consistent with one another completely based on the research of the bank, not on the basis of the other party's understanding. Such as this research documents is called research based on face (appear on their face).

Based on Article 14b of UCP 600, the bank in examining the documents has a maximum of 5 (five) banking days after the presentation day to determine the appropriate presentation. In Article 15 of UCP 600 mentions that the issuing bank and the confirming bank are obliged to undertake honor or negotiation of the 
appropriate presentation. This means that once the issuing bank or confirmation bank has established the appropriate presentation under Article 14b of UCP 600, then based on Article 15 of UCP 600 issuing bank or confirmation bank enters the settlements process for honor or negotiate. In essence Article 15 of UCP 600 contains the obligation to pay when the presentation is appropriate, without arranging when the realization of the honor or negotiate.

\section{Weaknesses of Letter of Credit}

$\mathrm{L} / \mathrm{C}$ is said to be an effective payment method, providing payment guarantee for exporters as well as guaranteed fulfillment of documents for the interests of importers. However, in practice, the method of payment with $\mathrm{L} / \mathrm{C}$ is not fully able to run effectively, this is evidenced by the various deficiencies contained in the payment method using $\mathrm{L} / \mathrm{C}$, among others as follows:

(1) The L/C is very concerned with "complying presentation" which is the presentation of documents that meet the terms and conditions of Letter of Credit, applicable UCP requirements, and international banking standard practices, so that payments are made by banks only on the basis of documents.

(2) If the document contains discrepancies, then even if the goods have been shipped/shipped in accordance with the order, the exporter has the potential to not receive the payment or receive the payment with discrepancy fee deducted.

(3) In the event of fraud, the exporter/beneficiary will not receive a payment even if all documents submitted meet the requirements.

Under the principle of independence, the $\mathrm{L} / \mathrm{C}$ is a contract independent of its basic contract. The sales contract, $\mathrm{L} / \mathrm{C}$ issuance contract, $\mathrm{L} / \mathrm{C}$ contract between issuing bank and beneficiary, agency contract is interrelated in business, but legally those contracts could not be attributed one to another.

\section{Analysis of Results}

In the case of KGK, BAPINDO has ignored the principles of prudence and supervision, in this case the Legal Lending Limit (LLL). The provision of credit of 1.3 trillion has exceeded the limits considered to violate the principles of prudence and supervision.

This prudent principle is one of the concretizations of the principle of trust in a lending, in addition also as an embodiment of prudent banking principles of all banking activities. Act Number 7 of 1992 concerning Banking (as amended by Act Number 10 of 1998), has obliged banks to conduct business in accordance with prudential principles in Article 29 paragraph (3). Application of Know Your Customer Principle or Know Your Customer Principle (KYC Principle) is also in the framework of application of prudential banking.

The failure of the debtor to not perform the obligation to return the credit as agreed has been a default. Therefore, it actually entered the scope of civil law. However, due to many violating banking rules such as violation of the principle of prudence and supervision that ultimately lead to losses of the state, so that based on civil provisions can lead to economic crime that is based on the provisions of criminal law. Based on the banking provisions of Act No. 3 of 2004 concerning Amendment to Act No. 23 of 1999 concerning Bank Indonesia with reference to Article 24 concerning bank duties and supervision, Article 25 paragraph (1) deals with the principles of prudence as well Article 29 paragraph (1, 2, and 3) concerning LLL provisions. In addition, in Act Number 10 of 1998 concerning Amendment to Act Number 7 of 1992 concerning Banking stipulated in Article 11 paragraph (1) on the provisions concerning LLL. In addition, in Act Number 10 of 1998 concerning Amendment to Act Number 7 of 1992 concerning Banking is contained in Article 11 paragraph (2) 
on the provisions concerning LLL which is not exceed 30\% of the bank capital.

According to the provisions of Act No. 10 of 1998 concerning Amendment to Act No. 7 of 1992 concerning Banking, the bank must be careful in carrying out its business activities, the precautionary principle is specified in Article 2. With regard to fictitious L/C transactions, the bank's prudence principles include the beneficiary of $\mathrm{L} / \mathrm{C}$, the introduction of the beneficiary, to the beneficiary's reputation, the ability of the beneficiary to carry out the transactions as referred to in the L/C. Violation of the provision may be punishable by imprisonment and a fine penalty under Article 49 paragraph (2) letter b Act number 10 of 1998 concerning Banking.

Any offense as a violation of prohibitions or obligations under the law is essentially an act of law (Onrechtmatige Handeling) as the main requirement shall comply with all elements of the offense as formulated in a law intentionally or unintentionally committed by a person who is accountable and by law has been declared a punishable offense. The criminal act is said to be straftbaarfeit.

In general, the potential deviations that may occur when applying for the issuance of $\mathrm{L} / \mathrm{C}$ facilities are among others the debtor using fictitious or falsified supporting documents, resulting in fictitious transactions and as if there is a legal relationship between the importer (applicant) and the exporter (Beneficiary), or both of the parties only done the paper trade. In this case of course the bank will be harmed, because the LC facility can be disbursed by the debtor. However, fictitious transactions using these L/C facilities usually also often involve internal parties from the bank itself. In the event of a falsification of documents at the time of submission of an LC facility involving an internal bank, it is appropriate to implement Article 49 paragraph (1) letter a of the Banking Act for the internal parties involved. The use of Article 49 Paragraph (1) Sub-Paragraph a (Act Number 10 of 1998) relates to fraudulent crimes with in bookkeeping, business activity reports, bank account transactions.

Banking Law number 10 of 1998 is a criminal act with specific perpetrators, only applicable to the Commissioners of the Bank, Board of Directors of Banks, and Bank Employees. That is, the perpetrators of crime in Article 49 are internal banks themselves. If a bank employee conspires with an outside bank conducting a criminal offense, then the bank's employees are subject to bank laws while outsiders are subject to the Criminal Code.

Under the provisions of the Criminal Code, the perpetrators of criminal acts in the banking sector may be charged under Article 55 paragraph (1) first book of the Criminal Code, Article 264 paragraph (2) in conjunction with Article 55 paragraph (1) to the Criminal Code, and Article 263 paragraph (1) in conjunction with Article 55 paragraph (1) of the Criminal Code.

Article 264 paragraph (2) in conjunction with article 55 paragraph (1) first book of Criminal Code, aimed at the act of forgery or falsifying the letter. Counterfeiting or falsifying the letter mentioned in Article 264 of the Criminal Code is committing an act of falsifying a pre-existing letter or falsifying a letter that has been specified criteria. This is different from the definition of Article 263 of the Criminal Code which is to make a fake letter that has not existed before with the aim to give rise to rights.

Article 263 paragraph (1) of the Criminal Code contains elements of who, makes false or falsified letters, which may give rise to any right, contract, or debt relief, or designated as evidence of a thing, with the intent to use or order others to wear. The letter seems to be true and not false, such use may result in harm, those who do, order to do or participate in doing.

Banking crime cases both banks as a pure victims or involve the internal of the bank by utilizing the 
weakness of $\mathrm{L} / \mathrm{C}$ often occur in Indonesia, including the case of $\mathrm{L} / \mathrm{C}$ Bank Pembangunan Indonesia (BAPINDO) - Golden Key Group (GKG) or the case of fictitious L/C BNI (known as Gramarindo Group-BNI case), and so many. Historical records prove that bank break-ins through $\mathrm{L} / \mathrm{C}$ facilities always occur over and over again and in large numbers, even though the system and security procedures in the banking system have been improved along with the occurrence of such cases. Still does not rule out the possibility of the same case. The involvement of internal bank is very strong role and its effect on the occurrence of crime in banking through L/C facility.

\section{Conclusions}

Criminal actions in the field of banking by buyers and sellers may occur by exploiting the weaknesses of L/Cs that are particularly concerned with "complying presentation”, i.e. presentation of documents that meet the requirements of L/C, applicable UCP regulations and international banking standard practices. So payments are made by banks only on the basis of documents without any physical verification of the transactions taking place.

The effort to overcome the criminal act in the banking sector conducted by the internal bank is charged with Act Number 10 of 1998 concerning Banking which clearly states that the legal subjects or perpetrators of criminal acts in committing the crime of false registration are determined in a limitative manner, namely the Board of Commissioners, Directors, or bank employees who are all officers and employees of the bank, while persons outside the bank are subject to the Criminal Code.

\section{References}

Adolf, H. (2009). International trade law (3rd ed.). PT. Raja Grafindo Persada, Jakarta, 47.

Amir, M. S. (2005). Letter of credit; with special discussion standby L/C in import export business. Jakarta, PPM Publisher, 3

Amir, M. S. (2007). As quoted by Agus Svarnha Nurpatria, Sale and purchase agreement by using L/C (Letter of Credit) at CV. Golden Teak Garden Semarang (pp. 48-49).

Andhibroto, S. (1997). Letter of credit in theory and practice. Semarang: Dahara Prize, 160.

Bank Indonesia, Banking Provisions of Act Number 3 Year 2004 concerning Legal Lending Limit, Article 24-25, 29.

Bank Indonesia Circular Letter in the UCP 500 enforcement setting.

Bank Indonesia, Foreign Affairs, Research Section and Foreign Payment Traffic Arrangement. (1995). International payment methods letter of credit \& non-letter of credit, 2.

Bank Indonesia. Beware with a tantalizing offer. http://www.bi.go.id/NR/rdonlyres/D645AC7A-6179-812-BF47 18F48F35DBF5 /1486/Beware with A Tantalizing Offer.pdf. Downloaded October 20, 2015.

BPP. (1991). Trade Finance-Payments and Services, 237, 245, 247

Center for Communication and Information, Public Relations of Polda Metro Jaya. White Collar Crime (White Crime). http://humaspoldametrojaya.blogspot.com/2009/white-collar-crime-kejahatan-kerah-putih.html, downloaded 18 October 2015.

Circular Letter of BI Number 26/34 /ULN dated December 17, 1993.

Decree of the Minister of Justice of the Republic of Indonesia Number M01.PW.07.03 Year 1982.

Ec, W. (2009). Letter of credit: A guide to the impact of the new rules of UCP 600 (1st ed.). Komexindo.press, Surabaya, 24-25, 27

Economic Development and Crime. Collection of Essay Books. (Jakarta: Center for Justice Services and Legal Services, 1994).

Ginting, R. (2008). International business and banking transactions (2rd ed.) (Revised). Salemba Empat, Jakarta, 2

HAK Moch Anwar, Crime in Banking, (Bandung: Alumni, 1986). See also Marjono Reksodiputro, Progress of Setiadi, Edi and Rena Yulia, Economic Criminal Law, Yogyakarta, Graha Ilmu, 2010.

Hadisoeprapto, H. (1991). Letter of credit payment method in commerce buying (2rd ed.). Yogyakarta: Liberty, 28-29.

Hartono, C. F. G. Sunaryati, as quoted by Ramlan Ginting, 15. 
Hatta, S. G. M. (2016). Credit and banking challenges. http://www.legalitas.org/database/artikel/perdata/perkreditan.pdf, downloaded January 19, 2016.

Hermansyah. (2006). Indonesian banking law. Kencana, Jakarta, 149, 151, 156

Husein, Y. (2010). Bank secrets and law enforcement (1st ed.). Jakarta: Juanda Tiga Lima Library, 18, 26, 162.

Indonesia, Book I of Criminal Code, Article 55.

Indonesia, Book II of Criminal Code, Chapter X, Article 244-246, 249-250, 263-264, 362-363, 372, 378.

Indonesia, Criminal Procedure Code (KUHAP), Article 284.

Indonesia, Government Regulation Number 1 Year 1982 on the Association of Foreign Exchange Flows Regulations.

Laws of Republic Indonesia, Number 10 Year 1998 about Amendment to Law of Number 7 Year 1992 on Banking, Article 6, 11, 29, 46-52.

Laws of Republic Indonesia, Number 20 Year 2001 on Amendment to Law Number 31 Year 1999 on the Eradication of Corruption.

Laws of Republic Indonesia, Number 30 Year 2002 on Corruption Eradication Commission.

Marpaung, L. (2005). Eradication and prevention of crime against banking. Djambatan, Jakarta, 79, 82-83

Megrah, M. Risk aspects of the irrevocable documentary credit, as quoted by Ramlan Ginting, Op. Cit., 217. 219-220, 225.

Mulyadi, L. (2007). Corruption in Indonesia, normative, theoretical, practice and problems (Printed 1). Bandung: Alumni, 2.

Neni, S. I. (2010). Introduction to Indonesian banking law (1st ed.). Bandung: Refika Aditama, 143, 172, 178.

Sutan, R. S. (2003). Money laundering: Understanding, historical, causal factors, and their impacts to society. Business Law, $1.22(3), 6$.

Rizal, A, M. (2015). Misuse of BLBI funds as white collar crimes in Indonesia. http://sjd.pdii.lipi.go.id/admin/jurnal/272084 854.pdf, downloaded October 18, 2015.

Sawidji, Y. (1996). Indonesian penal policy on organized crime. (Paper presented at Seminar on Penal Policy, FH UGM Yogyakarta, 3 September 1996), p. 9.

Setiadi, E., \& Yulia, R. (2010). Economic criminal law. Yogyakarta, Graha Ilmu, 139-140, 143-144

Sitompul, Z. (2007). Banking crime and money laundering. http://zulsitompul.files.wordpress.com/2007/06/makalah_seminar-padang.pdf. Downloaded October 20, 2015, p. 7.

Soehandjono. (2002). Required “drigen” with a political umbrella to complete the BLBI case. Gatra (February 2), p. 5.

Supaijo. (2015). Criminal policy in crime management in the field of Banking. http://jurnal.pdii.lipi.go.id/admin/jurnal/72081661.pdf, downloaded October 15, 2015.

Sutedi, A. (2016). Juridical review letter of credit and syndicated credit. Bandung, Alfabeta, 6, 21, 73.

Uniform Customs and Practice for Documentary Credit. (1974). ICC Publication No. 290 (UCP 290) revised.

Uniform Customs and Practice for Documentary Credit. (1994). ICC Publication No. 500 (UCP 500), Article 1, 2, 4, 6, 7, 9, 9b, 10, 13a, 14, 15, 18, 19, 48, 49.

Uniform Customs and Practice for Documentary Credit. (2007). ICC Publication No. 600 (UCP 600), Article 5, $14,15,34$.

Wijaya, K. (2015). Revitalization of banking http://www.infobanknews.com/2011/03/revitalization-controlling-banking-2/, downloaded 15 October 2015 